\title{
Studies on the nutrition of salmonid fish. The magnesium requirement of rainbow trout (Salmo gairdneri)
}

\author{
BY D. KNOX, C. B. COWEY AND J. W. ADRON \\ Institute of Marine Biochemistry, St Fittick's Road, Aberdeen ABI 3RA
}

(Received 20 June 1979 - Accepted 17 July 1980)

1. Rainbow trout (Salmo gairdneri) of mean initial weight $35 \mathrm{~g}$ were given one of five experimental diets for 20 weeks. The diets contained $(\mathrm{g} / \mathrm{kg}$ dry diet) 15 calcium, 10 phosphorus and graded levels of magnesium from 0.04 (diet no. 1) to 1.0 (diet no. 5). In a second experiment rainbow trout of mean initial weight $16 \mathrm{~g}$ were given one of six experimental diets for 20 weeks. The diets contained $(\mathrm{g} / \mathrm{kg}$ dry diet): $\mathrm{Ca}(40), \mathrm{P}(30)$ and levels of $\mathrm{Mg}$ from 0.06 (diet no. 6) to 2.0 (diet no. 11).

2. In both experiments weight gains were lowest in those trout given diets containing the basal levels of $\mathrm{Mg}$ (diet no. 1 and diet no. 6) but increased with increasing dietary Mg concentration. In neither experiment was there any further increase in weight gain once the $\mathrm{Mg}$ concentration reached $0 \cdot 25-0.5 \mathrm{~g} / \mathrm{kg}$ dry diet; weight gain reached a plateau at this dietary $\mathrm{Mg}$ level.

3. The following trends occurred in serum electrolyte concentrations as dietary $\mathbf{M g}$ increased. $\mathrm{Mg}$ increased in both experiments, in Expt 2 it reached a maximum of $1 \mathrm{mmol} / \mathrm{l}$ when the diet contained $0.5 \mathrm{~g} \mathrm{Mg} / \mathrm{kg}$ and did not increase further; sodium was positively correlated in both experiments; potassium decreased and in Expt 2 reached a plateau minimum of $1.7 \mathrm{mmol} / 1$ at a dietary $\mathrm{Mg}$ concentration of $0.5 \mathrm{~g} / \mathrm{kg} ; \mathrm{Ca}$ and $\mathrm{P}$ altered little in either experiment.

4. In both experiments renal Ca concentrations were greatly increased in trout given diets lacking supplementary $\mathrm{Mg}$; they fell to low levels (3-5 mmol $/ \mathrm{kg}$ ) when diets contained $0 \cdot 15 \mathrm{~g} \mathrm{Mg} / \mathrm{kg}$ or more. Renal $\mathrm{K}$ and $\mathrm{P}$ concentrations were negatively correlated with dietary $\mathrm{Mg}$ in Expt 2; other electrolytes measured were not altered in concentration by the treatments used.

5. Extracellular fluid volume (ECFV) of muscle was negatively correlated with dietary $\mathbf{M g}$. In Expt 2 it reached a minimal or normal value at $0.5 \mathrm{~g} \mathrm{Mg} / \mathrm{kg}$ diet and did not decrease further. Muscle $\mathrm{Mg}$ concentration increased with diet $\mathrm{Mg}$ in both experiments and muscle $\mathrm{K}$ concentration was also correlated with diet $\mathbf{M g}$ in Expt 2 . These changes were related to the shift in muscle water. In Expt 1, P concentration was decreased with increasing diet Mg but in Expt 2 its concentration increased, these changes may have been connected with the three-fold difference in dietary $P$ in the two experiments.

6. By contrast with skeletal muscle, $\mathrm{Mg}$ levels in cardiac muscle increased at low dietary $\mathrm{Mg}$ intakes.

7. Concentrations of electrolytes in liver did not alter with the dietary treatments used.

8. The results show that $\mathrm{Mg}$ requirement of rainbow trout is met by a diet containing $0.5 \mathrm{~g} \mathrm{Mg} / \mathrm{kg}$ diet.

The effects of magnesium deficiency on rainbow trout (Salmo gairdneri) given diets containing different amounts of calcium and phosphorus were recently described (Cowey et al. 1977). Some of the pathologies found were similar to those described in carp (Cyprinus carpio) by Ogino \& Chiou (1976) and later in rainbow trout by Ogino et al. (1978), namely poor growth and sluggishness. In addition, calcinosis of kidney and muscle was also demonstrated; electron probe micro-analysis of the renal calculi showed that the deposits contained tricalcium phosphate (Cowey et al. 1977).

Since many materials used as components of practical fish diets may contain large amounts of $\mathrm{Ca}$ and $\mathrm{P}$, e.g. fish meal, shrimp meal, the present work was undertaken to examine the $\mathrm{Mg}$ requirement of rainbow trout given either low or high dietary levels of $\mathrm{Ca}$ and $P$. To this end two experiments were carried out. In the first, diets containing $(\mathrm{g} / \mathrm{kg}$ dry diet) $15 \mathrm{Ca}$ and $10 \mathrm{P}$ and graded amounts of $\mathrm{Mg}$ were given to groups of rainbow trout of mean initial weight $35 \mathrm{~g}$ for 20 weeks. In the second, diets containing $(\mathrm{g} / \mathrm{kg}$ dry diet) $40 \mathrm{Ca}$ and $30 \mathrm{P}$ together with various levels of $\mathrm{Mg}$ were given to groups of rainbow trout of mean initial weight $16 \mathrm{~g}$, again for 20 weeks. 
Renal calcinosis, as well as an increase in muscle extracellular fluid volume (ECFV) occurred as a consequence of $\mathrm{Mg}$ deficiency in both experiments. An $\mathrm{Mg}$ level of $0.5 \mathrm{~g} / \mathrm{kg}$ dry diet was found to be adequate for rainbow trout in that, in both experiments, weight gain reached a plateau at this concentration and no pathologies or other abnormalities were evident.

\section{MATERIALS AND METHODS}

The experiments were carried out sequentially. In the first experiment, five dietary treatments were used, the intended dietary $\mathrm{Ca}$ and $\mathrm{P}$ levels being respectively 15 and $10 \mathrm{~g} / \mathrm{kg}$ diet with five dietary $\mathrm{Mg}$ levels. In the second experiment the intended dietary $\mathrm{Ca}$ and $\mathrm{P}$ levels were 40 and $30 \mathrm{~g} / \mathrm{kg}$ diet, and six dietary $\mathrm{Mg}$ concentrations were used. A dietary $\mathrm{Ca}: \mathrm{P}$ value of 1.5:1 was used in the diets with a view to the levels of $\mathrm{Ca}$ and $\mathrm{P}$ that might be obtained in a trout diet when fish meal or shrimp meal for example was used as a main ingredient. Chemical analyses of white fish meal showed $\mathrm{Ca}$ and $\mathrm{P}$ concentrations $(\mathrm{g} / \mathrm{kg})$ of $\mathbf{8 0}$ and 35 respectively. Furthermore, analysis of a number of commercial trout pellets has shown $\mathrm{Ca}: \mathrm{P}$ values ranging from $1: 1$ to $2: 1$.

Rainbow trout were obtained from D. M. Brien, Almondbank, Perth; they had been reared on a commercial trout diet. For the first experiment the fish obtained had a mean weight of approximately $35 \mathrm{~g}$, they were given diets $1-5$ (Table 1). For the second experiment smaller fish were supplied (mean weight approximately $16 \mathrm{~g}$ ). They were given diets 6-11 (Table 1). In each experiment the rainbow trout were randomly distributed among circular glass-fibre tanks of diameter $1 \mathrm{~m}$, depth $0.6 \mathrm{~m}$ and each containing $400 \mathrm{l}$ water. The water from the tanks was partially recirculated, with a constant 'bleed-in' of fresh tap-water (75 1/tank per h) from the City of Aberdeen domestic supply. The $\mathrm{Mg}$ and $\mathrm{Ca}$ concentration in the aquarium water was monitored during the experiments; the mean concentrations (mmol/l) found were $\mathrm{Mg} 0.05$ and $\mathrm{Ca} \mathrm{0.30}$. The tanks were housed in an aquarium room with an ambient temperature averaging $15^{\circ}$.

The fish were first given a diet identical to the experimental diet used, but containing $(\mathrm{g} / \mathrm{kg}$ dry diet) $15 \mathrm{Ca}, 10 \mathrm{P}$ and $1 \mathrm{Mg}$ for the first experiment, and $40 \mathrm{Ca}, 30 \mathrm{P}$ and $1 \mathrm{Mg}$ for the second experiment.

The trout were given this diet until they appeared to have acclimatized to their surroundings, feeding routine, diet, light etc. Initial weight measurements were then made as previously described (Cowey et al. 1977), thereafter the fish were weighed every 4 weeks throughout the experiments which lasted for 20 weeks. The trout were fed to satiation four times daily ( $6 \mathrm{~d} /$ week), food pellets being put sparingly into each tank only so long as they were actively consumed.

The diets used were prepared as before (Cowey et al. 1977). The composition of all the diets, including the measured levels of $\mathrm{Ca}, \mathrm{Mg}$ and $\mathrm{P}$ are shown in Table 1 . In diets 10 and 11 part of the added $\mathrm{Mg}$ was provided as magnesium acetate instead of magnesium sulphate since it was thought that very high levels of sulphate in the diet might be detrimental to the fish.

\section{Chemical methods}

Serum from blood obtained from the caudal vein, and samples of kidney, muscle, liver and heart were collected, stored, ashed and analysed as previously (Cowey et al. 1977). Analyses were carried out on six fish selected by random methods from each dietary treatment.

The estimate of muscle ECFV used was the chloride space, this was measured by the methods of Manery (1954) adapted as follows: six randomly selected fish from each dietary treatment were anaesthetized with ethyl-m-aminobenzoate, methane sulphonic acid salt (Sigma Chemical Company, Fancy Road, Poole, Dorset) at a concentration of $0.2 \mathrm{~g} / \mathrm{l}$. The fish were then injected intravenously with $2 \mu \mathrm{Ci}{ }^{38} \mathrm{Cl}$ (Radiochemical Centre, Amersham, 
Studies on the nutrition of salmonid fish

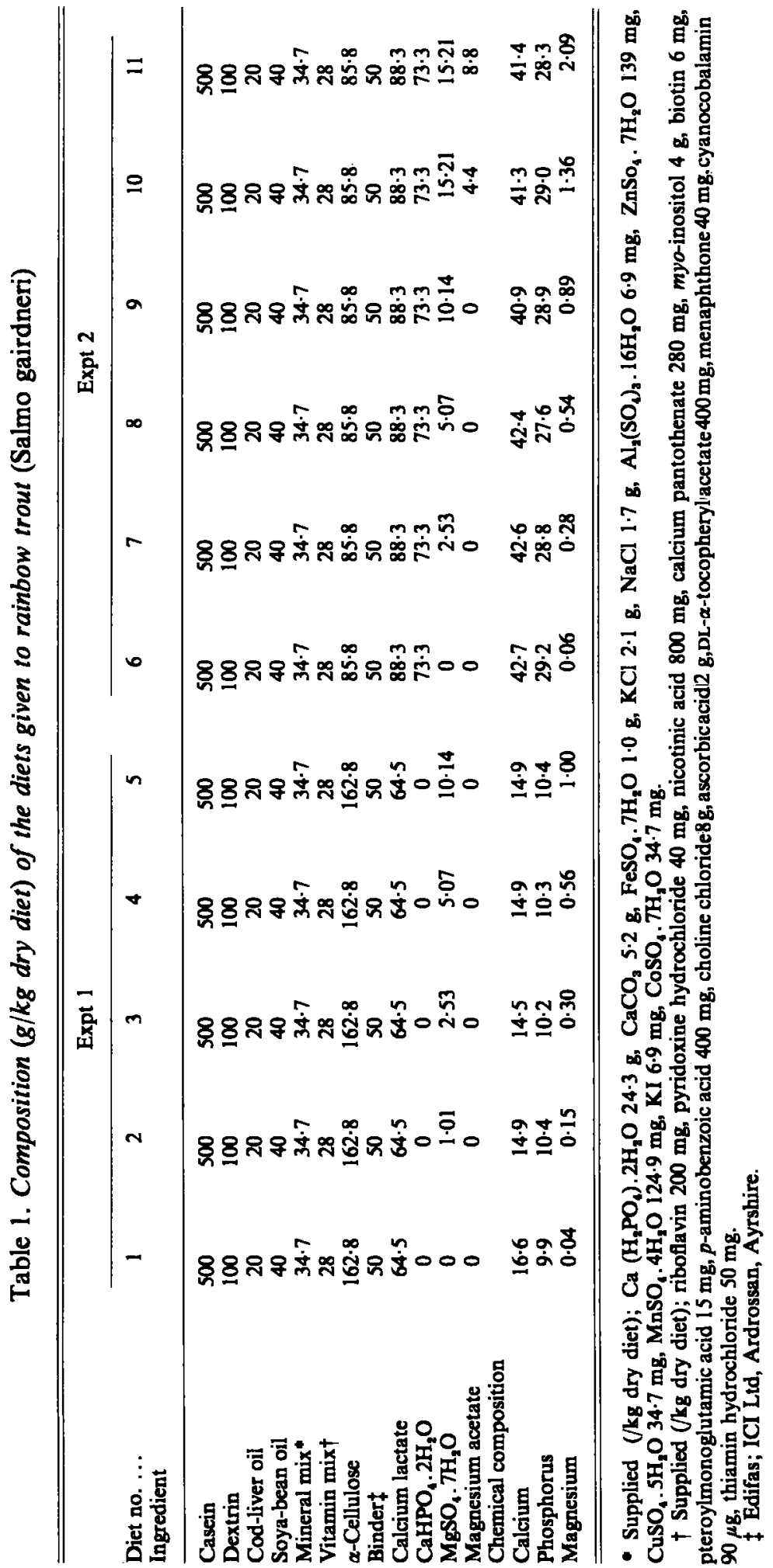


Bucks) in $0.1 \mathrm{ml}$ saline solution ( $9 \mathrm{~g}$ sodium chloride $/ 1)$. After a $5 \mathrm{~h}$ equilibration period, to allow complete mixing and penetration of the whole $\mathrm{Cl}$ space, the fish were killed by cervical dislocation and samples of skeletal muscle and plasma were collected. A piece of excised muscle $(1 \mathrm{~g})$ was rapidly removed and homogenized in $5 \mathrm{ml}$ distilled water and then $1.25 \mathrm{ml}$ trichloroacetic acid $(500 \mathrm{~g} / 1 ; \mathrm{TCA})$ added to the homogenate. After thorough mixing the homogenate was centrifuged at $2500 \mathrm{~g}$ for $10 \mathrm{~min}$ at room temperature. The total water content of muscle and plasma was measured by drying a known weight of each tissue at $100^{\circ}$ for $18 \mathrm{~h}$. The measured muscle water content was then used to calculate the total volume of each muscle homogenate. Portions of the TCA supernatant fraction and plasma from each fish were assayed for ${ }^{36} \mathrm{Cl}$ using a liquid scintillation spectrometer, the amounts of ${ }^{38} \mathrm{Cl}$ being expressed as counts/min per 1 plasma or counts/min per $\mathrm{kg}$ muscle. Then the muscle ${ }^{36} \mathrm{Cl}$ space was calculated for each fish by substituting values in the equation of Manery (1954).

Muscle ${ }^{36} \mathrm{Cl}$ space g water $/ \mathrm{kg}$ muscle $=\frac{{ }^{36} \mathrm{Clm} \times \mathrm{H}_{2} \mathrm{Op} \times \mathrm{rCl}}{{ }^{36} \mathrm{Clp}}$, where ${ }^{36} \mathrm{Clm}$ is muscle ${ }^{36} \mathrm{Cl}$ content (counts/min per kg muscle), ${ }^{36} \mathrm{Clp}$ is plasma ${ }^{38} \mathrm{Cl}$ content (counts/min per 1 plasma), $\mathrm{H}_{2} \mathrm{Op}$ is plasma water content (ml/kg plasma), $\mathrm{rCl}$ is Gibbs-Donnan ratio for $\mathrm{Cl}(0.977)$, Holmes \& Donaldson, 1969.

Correlation coefficients among the experimental results were determined as described by Fisher (1950).

\section{RESULTS}

Although the two experiments involved trout of different mean initial weights, and which differed in age by approximately 8 weeks, for ease of presentation, measurements of the same variable are shown together and diets are numbered consecutively.

In both experiments growth and mortality rate were affected by dietary $\mathrm{Mg}$ intake (Table 2) the lowest weight gain and the highest rate of mortality occurred in those fish given diets lacking supplementary $\mathrm{Mg}$ (diet no. 1 and diet no. 6 containing 0.04 and $0.06 \mathrm{~g} \mathrm{Mg} / \mathrm{kg}$ dry diet respectively). Weight gain reached a maximum, in both experiments, when the concentration of $\mathrm{Mg}$ in the diet was $0.25-0.5 \mathrm{~g} / \mathrm{kg}$, it did not increase with further rise in dietary $\mathrm{Mg}$ up to levels of $1 \mathrm{~g} / \mathrm{kg}$ (Expt 1) and $2 \mathrm{~g} / \mathrm{kg}$ (Expt 2). In those trout given diets without supplementary $\mathrm{Mg}$ a higher rate of mortality was evident in Expt 2 (those trout given diet no. 6) than in Expt 1 (diet no. 1). This may have resulted either from the smaller size of the fish used in Expt 2 or from the higher dietary $\mathrm{Ca}$ and $\mathrm{P}$ concentrations used in that experiment.

Further symptoms of $\mathrm{Mg}$ deficiency shown by trout were a flaccidity of the muscle and sluggishness (that is they were very easily caught by hand net and removed from the tank at times of weighing). There was little sign of loss of appetite; food consumption was very similar on all dietary treatments during the first 12 weeks of each experiment amounting to $25 \mathrm{~g} / \mathrm{kg}$ biomass trout per $\mathrm{d}$. Thereafter there was a slight fall in food intake on all treatments but even during weeks 19 and 20 consumption by fish given diet no. 1 (Expt 1) was $18 \mathrm{~g} / \mathrm{kg}$ biomass trout per $\mathrm{d}$. This compares with values of $(\mathrm{g} / \mathrm{kg}$ biomass trout per d) $21,20,21$ and 22 for fish given diet nos. 2-5 respectively. A similar pattern of food consumption was found in Expt 2.

The concentrations of certain minerals in the sera are shown in Table 3. In Expt 1 there was a positive correlation between serum $\mathrm{Mg}$ concentration and dietary $\mathrm{Mg}(r \mathbf{0} \cdot 72, n 28$, $P<0.001)$. For the smaller fish used in Expt 2 serum $\mathrm{Mg}$ increased with dietary $\mathrm{Mg}$ to reach a plateau value of $1 \mathrm{mmol} / 1$ at a dietary $\mathrm{Mg}$ level of $0.54 \mathrm{~g} / \mathrm{kg}$, further increase in dietary $\mathbf{M g}$ did not lead to any further increase in serum $\mathbf{M g}$ concentration. In this context it is noteworthy that in Expt 1 the highest serum $\mathrm{Mg}$ concentration found was 1.58 
Table 2. Initial numbers of fish, mean initial and final weights $(g)$ and mortalities of rainbow trout (Salmo gairdneri) given diets containing different amounts of calcium, magnesium and phosphorus

\begin{tabular}{|c|c|c|c|c|c|}
\hline & Diet no.* & $\begin{array}{l}\text { Initial no. } \\
\text { of fish }\end{array}$ & $\begin{array}{l}\text { Mean initial } \\
\text { wt (g) }\end{array}$ & $\begin{array}{c}\text { Mean final } \\
\text { wt (g) }\end{array}$ & Mortalities \\
\hline Expt 1 & $\begin{array}{l}1 \\
2 \\
3 \\
4 \\
5\end{array}$ & $\begin{array}{l}30 \\
27 \\
29 \\
28 \\
28\end{array}$ & $\begin{array}{l}33 \cdot 3 \\
35 \cdot 8 \\
35 \cdot 2 \\
34 \cdot 1 \\
35 \cdot 6\end{array}$ & $\begin{array}{r}88 \cdot 6 \\
122 \cdot 2 \\
144 \cdot 1 \\
152.3 \\
145 \cdot 4\end{array}$ & $\begin{array}{l}5 \\
2 \\
1 \\
0 \\
1\end{array}$ \\
\hline Expt 2 & $\begin{array}{r}6 \\
7 \\
8 \\
9 \\
10 \\
11\end{array}$ & $\begin{array}{l}32 \\
30 \\
31 \\
31 \\
32 \\
31\end{array}$ & $\begin{array}{l}16.1 \\
15.9 \\
17.0 \\
15.0 \\
17.7 \\
16.1\end{array}$ & $\begin{array}{l}46.3 \\
64.9 \\
67.3 \\
52.0 \\
59.8 \\
54.0\end{array}$ & $\begin{array}{r}11 \\
2 \\
3 \\
2 \\
2 \\
2\end{array}$ \\
\hline
\end{tabular}

* For details, see Table 1.

$\mathrm{mmol} / \mathrm{l}$ when $\mathrm{Mg}$ in the diet was $0.56 \mathrm{~g} / \mathrm{kg}$ while at the highest dietary $\mathrm{Mg}$ level used (1.0 $\mathrm{g} / \mathrm{kg}$ ) serum $\mathrm{Mg}$ concentration was $1.35 \mathrm{mmol} / \mathrm{l}$. By comparison with Expt 2 it thus appears likely that had it been possible to include higher dietary Mg levels in Expt 1 these would have shown that, in this experiment also, serum $\mathrm{Mg}$ concentration might have reached a plateau value above a certain dietary $\mathrm{Mg}$ level.

There was also a positive correlation between serum $\mathrm{Na}$ concentration and dietary $\mathrm{Mg}$ in both experiments. Serum $\mathrm{Na}$ increased from 106 to $154 \mathrm{mmol} / \mathrm{l}$ in Expt 1 as dietary $\mathrm{Mg}$ rose from 0.04 to $1.0 \mathrm{~g} / \mathrm{kg}$ diet $(r 0.63, n 28, P<0.001)$. Serum Na concentrations in Expt $2(r 0.63, n 34, P<0.001)$ were higher than those found in Expt 1 but the increase with rising dietary $\mathrm{Mg}$ was less marked than in Expt 1.

The trends seen in serum $K$ concentrations were the converse of those found with serum $\mathrm{Na}$ and $\mathrm{Mg}$. Over the range of dietary $\mathrm{Mg}$ concentrations used in Expt 1 serum $\mathrm{K}$ was negatively correlated with dietary $\mathrm{Mg}(r-0.58, n 28, P<0.001)$. In Expt 2 serum $\mathrm{K}$ fell to a concentration of $1.72 \mathrm{mmol} / \mathrm{l}$ at a dietary $\mathrm{Mg}$ level of $0.54 \mathrm{~g} / \mathrm{kg}$. This appeared to be a plateau minimum because serum $\mathrm{K}$ concentration did not change further as dietary $\mathrm{Mg}$ was raised to $2 \cdot 0 \mathrm{~g} / \mathrm{kg}$.

This elevation of serum $\mathrm{K}$ concentration in the $\mathrm{Mg}$-deficient trout is remarkable from a comparative viewpoint in that it contrasts with findings in rats. Elin et al. (1971) found no differences in the plasma $\mathrm{K}$ levels of $\mathrm{Mg}$-deficient and control rats while George (1976) also using rats found a significant decrease in plasma $\mathrm{K}$ in the $\mathrm{Mg}$-deficient animal.

Serum $\mathbf{P}$ concentration showed no obvious trend in either experiment with increasing dietary $\mathrm{Mg}$. Serum Ca concentration was also relatively constant in both experiments although trout given diets deficient in $\mathbf{M g}$ (diet no. 1, Expt 1; and diet no. 6, Expt 2) did show slight, but significant, hypercalcaemia. It may be noted that although dietary $\mathrm{Ca}$ and $\mathbf{P}$ levels differed markedly in the two experiments serum $\mathrm{Ca}$ and $\mathrm{P}$ levels were generally similar.

Renal Ca levels (Table 4) were elevated by more than three-fold in trout given the basal $\mathrm{Mg}$ diet in Expt 1; the kidney Ca concentrations in trout given diets containing increasing amounts of supplementary $\mathrm{Mg}(0.15-1.0 \mathrm{~g} / \mathrm{kg})$ were very constant with a mean value of $3.59 \mathrm{mmol} / \mathrm{kg}$ wet weight. The renal $\mathrm{Ca}$ level in trout given a diet lacking supplementary $\mathrm{Mg}$ in Expt 2 was more than double that found in the corresponding treatment in Expt 1. 


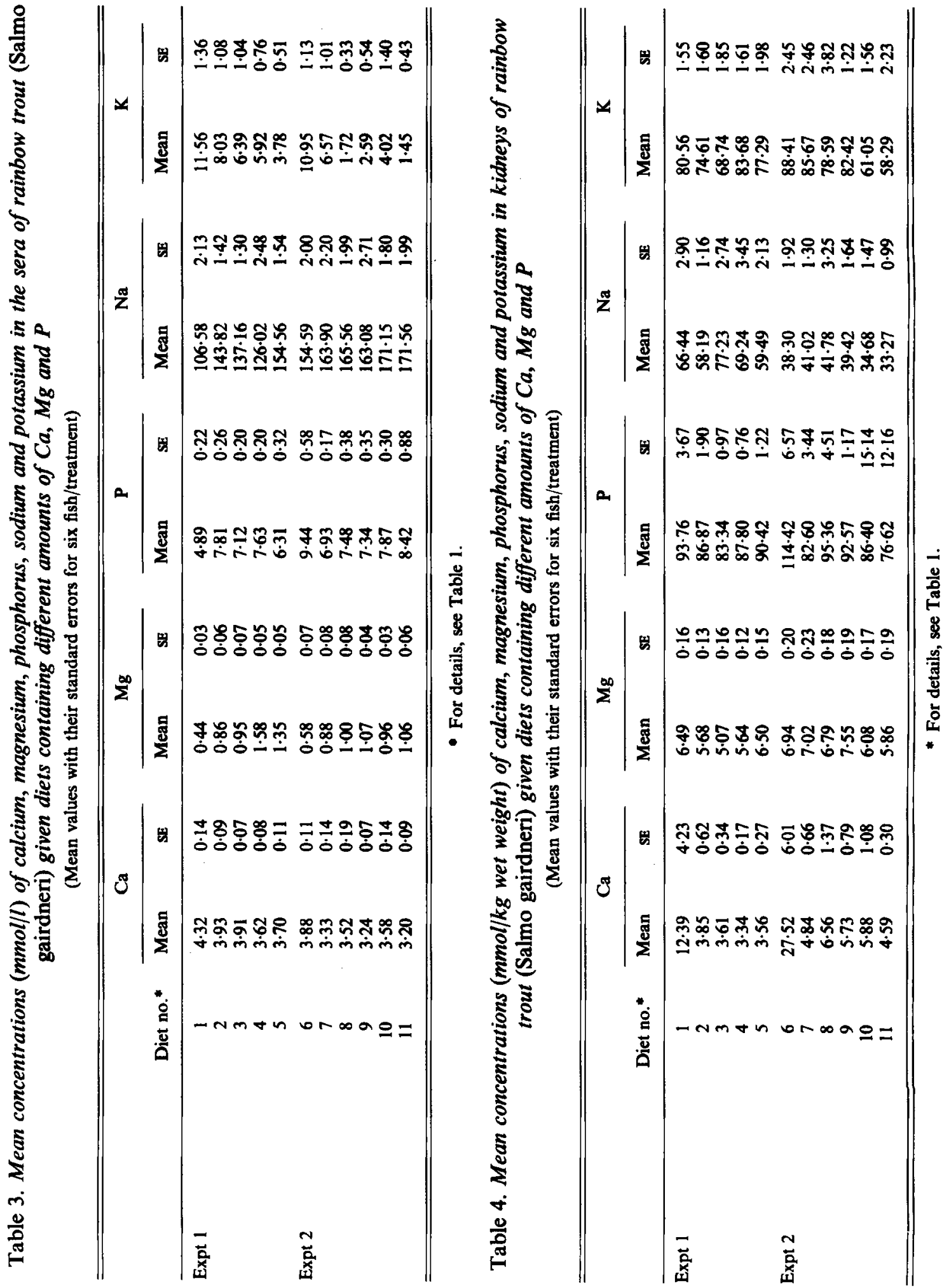


Studies on the nutrition of salmonid fish

(2)

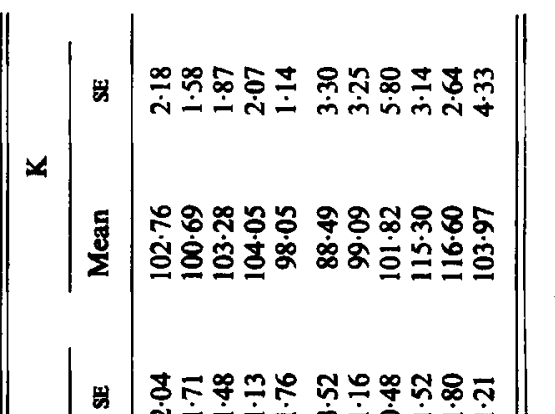

के

รูำ

$\rightarrow \infty$

รี

2

$\$ 0$

ริำ

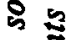

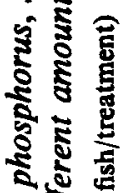

ริ

赵

क

马

於六市

圈

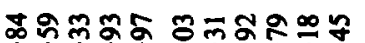

a

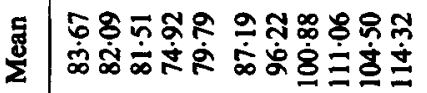

3

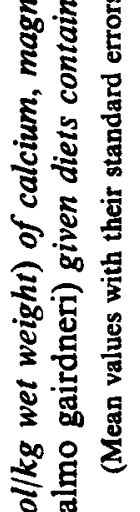

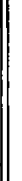

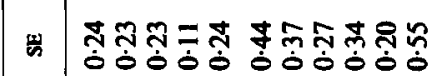

$\stackrel{\infty}{\Sigma}$

嵒

ஃ๐์

o

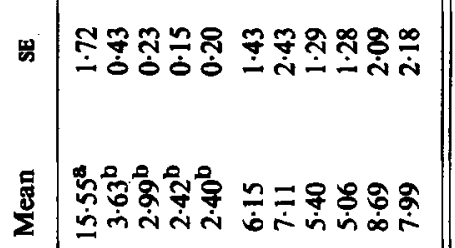

蛋

放

క్

:

:

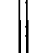

递

8

क

in

喜

苛 
Table 6. Mean levels ( $\mathrm{g}$ water $/ \mathrm{kg}$ wet weight) of total muscle water, extracellular fluid volume and intracellular fuid volume in the muscle of rainbow trout (Salmo gairdneri) given diets containing different amounts of calcium, magnesium and phosphorus

(Mean values with their standard errors for six fish/treatment)

\begin{tabular}{|c|c|c|c|c|c|c|c|}
\hline & \multirow[b]{2}{*}{ Diet no." } & \multicolumn{2}{|c|}{$\begin{array}{c}\text { Total muscle } \\
\text { water volume }\end{array}$} & \multicolumn{2}{|c|}{$\begin{array}{l}\text { Muscle extracellular } \\
\text { fluid volume }\end{array}$} & \multicolumn{2}{|c|}{$\begin{array}{l}\text { Muscle intracellular } \\
\text { fluid volume }\end{array}$} \\
\hline & & Mean & SE & Mean & $\mathbf{S E}$ & Mean & SE \\
\hline Expt 1 & $\begin{array}{l}1 \\
2 \\
3 \\
4 \\
5\end{array}$ & $\begin{array}{l}794 \cdot 5 \\
785 \cdot 6 \\
767 \cdot 7 \\
769 \cdot 3 \\
763 \cdot 7\end{array}$ & $\begin{array}{l}4.4 \\
3 \cdot 2 \\
2.3 \\
1 \cdot 1 \\
0.7\end{array}$ & $\begin{array}{r}194.1 \\
114.6 \\
117.5 \\
80.0 \\
65.8\end{array}$ & $\begin{array}{r}22.1 \\
4.3 \\
9.7 \\
3.3 \\
3.8\end{array}$ & $\begin{array}{l}600 \cdot 5 \\
671 \cdot 0 \\
650 \cdot 2 \\
689.3 \\
697.9\end{array}$ & $\begin{array}{r}17 \cdot 8 \\
5 \cdot 6 \\
9.8 \\
3 \cdot 2 \\
4 \cdot 0\end{array}$ \\
\hline Expt 2 & $\begin{array}{r}6 \\
7 \\
8 \\
9 \\
10 \\
11\end{array}$ & $\begin{array}{l}797 \cdot 9 \\
786 \cdot 7 \\
781 \cdot 3 \\
791 \cdot 9 \\
785 \cdot 2 \\
785 \cdot 2\end{array}$ & $\begin{array}{l}4 \cdot 2 \\
1 \cdot 7 \\
2 \cdot 7 \\
2 \cdot 1 \\
1 \cdot 9 \\
1 \cdot 9\end{array}$ & $\begin{array}{r}179.4 \\
83.5 \\
69.2 \\
53.4 \\
68.6 \\
72.5\end{array}$ & $\begin{array}{r}23.5 \\
9.0 \\
6.0 \\
1.0 \\
6.3 \\
4.5\end{array}$ & $\begin{array}{l}618.5 \\
702.6 \\
712.1 \\
738.5 \\
716.6 \\
714.8\end{array}$ & $\begin{array}{r}20.0 \\
8.4 \\
6.7 \\
8.8 \\
6.6 \\
2.4\end{array}$ \\
\hline
\end{tabular}

* For details, see Table 1.

Kidney Ca levels of trout given diets with supplementary $\mathrm{Mg}$ in Expt 2 tended to be more variable and were higher than those from Expt 1, mean kidney $\mathrm{Ca}$ level of these trout was $5.52 \mathrm{mmol} / \mathrm{kg}$ wet weight.

Renal $\mathrm{P}$ concentrations decreased as dietary $\mathrm{Mg}$ increased in Expt $2(r-0.51, n$ 34, $P<0.01)$ but this trend was not apparent in Expt 1 . A negative correlation between renal $\mathrm{K}$ concentration and dietary $\mathrm{Mg}$ was apparent in Expt $2(r-0.84, n 34, P<0.001)$. Again this trend was absent in Expt 1. In neither experiment were any trends discernible in the renal concentrations of $\mathrm{Mg}$ or $\mathrm{Na}$ in response to increasing intake of dietary $\mathrm{Mg}$.

Muscle mineral concentrations are shown in Table 5. In Expt 1 muscle $P$ concentration decreased as dietary $\mathrm{Mg}$ increased $(r-0.41, n 28, P<0.01)$ while muscle $\mathrm{Mg}$ concentration was positively correlated with diet $\mathrm{Mg}(r 0.66, n 28, P<0.01)$. No trends were evident in muscle $\mathrm{Ca}, \mathrm{K}$ or $\mathrm{Na}$ concentrations in Expt 1 although in trout given the diet 1, lacking supplementary $\mathrm{Mg}$, both muscle $\mathrm{Ca}$ and muscle $\mathrm{Na}$ concentrations were significantly greater than for other treatments $(P<0.01)$. In Expt 2 muscle $P$ concentration increased as dietary Mg increased $(r 0.71, n 34, P<0.001)$, muscle $\mathrm{K}$ concentration was also positively correlated with diet $\mathrm{Mg}(r 0.41, n 34, P<0.01)$. Muscle $\mathrm{Mg}$ concentration increased with dietary $\mathrm{Mg}$ up to a dietary $\mathrm{Mg}$ level of $0.54 \mathrm{~g} / \mathrm{kg}$ but did not increase further with rising dietary $\mathrm{Mg}$. The inflexion or plateau point in the muscle $\mathrm{Mg} / \mathrm{diet} \mathrm{Mg}$ response relationship occurred at a dietary $\mathrm{Mg}$ level of $0.5 \mathrm{~g} / \mathrm{kg}$. No trends were evident in muscle $\mathrm{Ca}$ or muscle $\mathrm{Na}$ concentration in Expt 2.

The distribution of water in the muscle of fish from the two experiments is shown in Table 6. In Expt 1 ECFV was $194 \mathrm{~g}$ water $/ \mathrm{kg}$ muscle when the diet (no. 1) contained no supplementary Mg; ECFV decreased as dietary Mg increased $(r-0.73, n 28, P<0.001)$ until with diet no. $5(1 \mathrm{~g} \mathrm{Mg} / \mathrm{kg})$ it had fallen within the normal range at $65.8 \mathrm{~g}$ water $/ \mathrm{kg}$ muscle. ECFV was $179.4 \mathrm{~g}$ water $/ \mathrm{kg}$ muscle in trout given diet no. 6 (Expt 2); in this experiment ECFV fell to a value of $69.2 \mathrm{~g}$ water $/ \mathrm{kg}$ (diet no. 8) but remained sensibly constant at this level as diet $\mathrm{Mg}$ increased to $2.0 \mathrm{~g} / \mathrm{kg}$.

Mineral concentrations in cardiac muscle of trout from the two experiments are shown 
Studies on the nutrition of salmonid fish

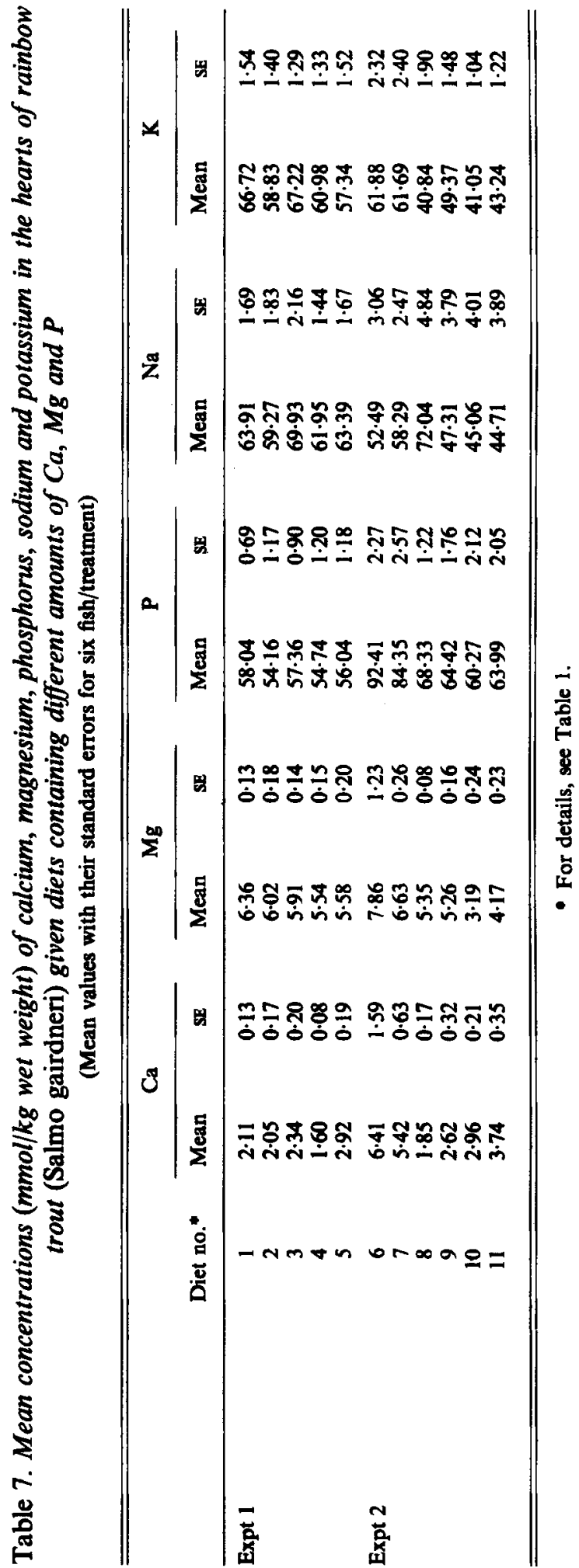


D. Knox, C. B. Cowey and J. W. Adron

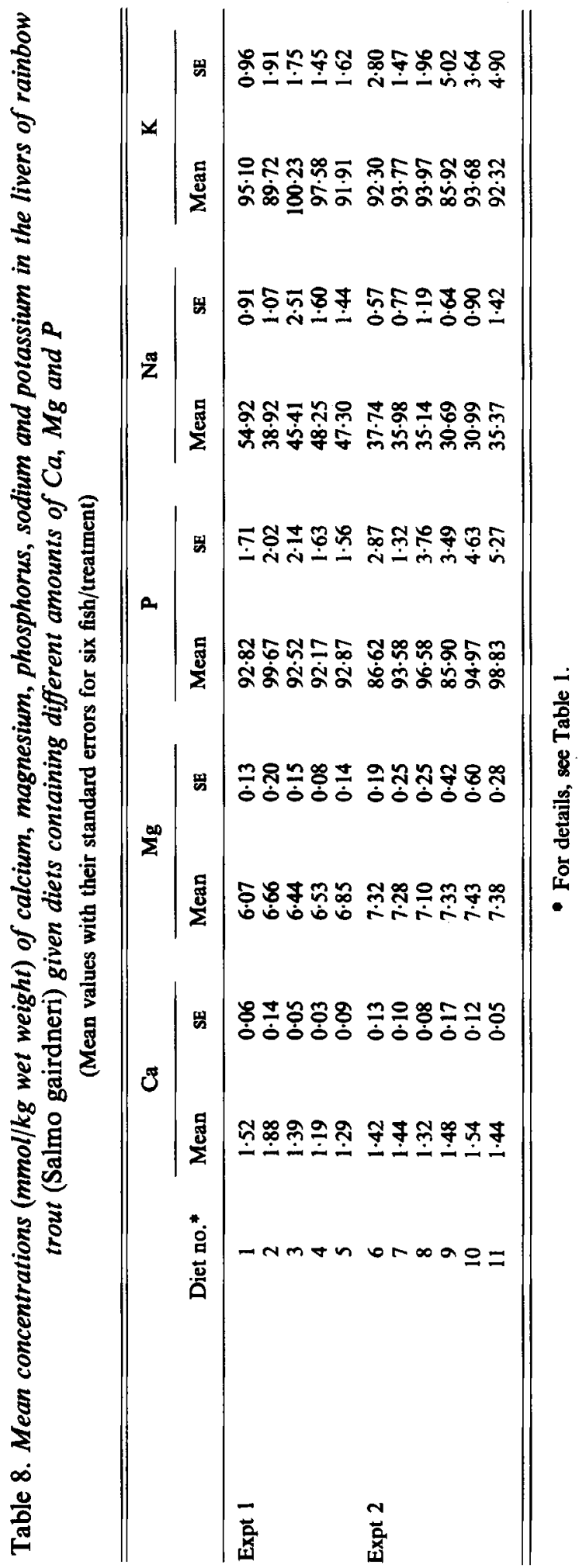


in Table 7. There was a slight but significant decrease in cardiac muscle $\mathrm{Mg}$ concentration as dietary $\mathrm{Mg}$ increased $(r-0.45, n 28, P<0.01)$ in Expt 1; no trends were evident in cardiac muscle concentrations of $\mathrm{Ca}, \mathrm{P}, \mathrm{Na}$ or $\mathrm{K}$ in Expt 1. Cardiac muscle $\mathrm{Mg}$ concentration was also negatively correlated with dietary $\mathrm{Mg}(r-0.7, n 34, P<0.001)$ in Expt 2. In this experiment the concentrations of both $\mathrm{Ca}$ and $\mathrm{P}$ decreased with increasing dietary $\mathrm{Mg}$ until the dietary level was $0.56 \mathrm{~g} \mathrm{Mg} / \mathrm{kg}$ thereafter the concentrations of $\mathrm{Ca}$ and $P$ remained relatively constant.

Concentrations of $\mathrm{Mg}, \mathrm{Ca}, \mathrm{P}, \mathrm{K}$ and $\mathrm{Na}$ in the livers of trout from the two experiments are shown in Table 8 . In this organ concentrations of all these minerals were relatively constant in both experiments.

\section{DISCUSSION}

It can be concluded from many of the results obtained in Expt 2 that the $\mathrm{Mg}$ requirement of rainbow trout in the weight range $16-60 \mathrm{~g}$ is satisfied by an $\mathrm{Mg}$ concentration in the diet of $0.5 \mathrm{~g} / \mathrm{kg}$. At this concentration weight gain, serum $\mathrm{Mg}$ and muscle $\mathrm{Mg}$ levels reached maximal (plateau) levels, similarly muscle ECFV and serum $\mathrm{K}$ reached constant levels and did not decrease further with increasing dietary $\mathrm{Mg}$. Mortalities were few at or above this dietary $\mathrm{Mg}$ level nor was there any calcinosis in the kidney.

Several of the results obtained in Expt 1 with trout in the weight range 30-150 g, given diets containing lower levels of $\mathrm{Ca}$ and $\mathrm{P}$ than those used in Expt 2, also indicate an $\mathrm{Mg}$ requirement of $0.5 \mathrm{~g} / \mathrm{kg}$ diet. Other possible criteria were less conclusive; in particular muscle ECFV, serum $\mathrm{K}$, serum $\mathrm{Mg}$ and muscle $\mathrm{Mg}$ gave different dose/response relationships than was the case in Expt 2. While these parameters changed in the direction anticipated with increasing dietary $\mathrm{Mg}$ concentration they did not reach a constant level. The most obvious explanation for this is that the range of dietary $\mathrm{Mg}$ concentrations used in Expt 2(0.06-2.0 $\mathrm{g} / \mathrm{kg})$ was double that in Expt $1(0.04-1.0 \mathrm{~g} / \mathrm{kg})$ so that in the latter experiment it was less easy to see where, with most variables, the limit of response had been reached. Despite the inconclusive nature of the results with muscle ECFV, serum $\mathbf{M g}$, serum $\mathrm{K}$ and muscle $\mathbf{M g}$ other evidence shows that in this experiment also, the $\mathrm{Mg}$ requirement is met at a dietary level of $0.5 \mathrm{~g} / \mathrm{kg}$. Thus, at or above this concentration, weight gain reached a plateau, few mortalities occurred and there was no renal calcinosis.

While this work was in progress Ogino et al. (1978) showed that an Mg concentration of $0.6-0.7 \mathrm{~g} / \mathrm{kg}$ dry diet was necessary to ensure optimum growth in rainbow trout fry (mean initial weight $0.9 \mathrm{~g}$ ) given a diet containing approximately $2.8 \mathrm{~g} \mathrm{Ca}$ and $4.6 \mathrm{~g} \mathrm{P} / \mathrm{kg}$ dry diet. Ogino \& Chiou (1976) had earlier shown that the $\mathrm{Mg}$ requirement of carp given diets similar to those used with the trout was $0.4-0.6 \mathrm{~g} / \mathrm{kg}$.

Studies carried out on guinea pigs and rats (O'Dell et al. 1960; McAleese \& Forbes, 1961) and on chicks (Nugura \& Edwards, 1963) have shown that when dietary Ca or P levels or both were raised the dietary $\mathrm{Mg}$ requirement increased. By contrast the results presented in this study do not indicate any increase in $\mathbf{M g}$ requirement as dietary levels of $\mathbf{C a}$ or $\mathbf{P}$ are increased.

In both experiments an increase in muscle ECFV was shown to be associated with an inadequate dietary $\mathrm{Mg}$ level. This substantiates previous explanations of changes in muscle composition during Mg deficiency (Cowey et al. 1977). Much earlier Elin et al. (1971) had obtained a similar result using $\mathbf{M g}$-deficient rats. Although the total muscle water content increased slightly in the $\mathrm{Mg}$-deficient fish, the main factor in the increased ECFV in both experiments appeared to be a shift of water from the intracellular to the extracellular compartment (Table 6). In rats this water shift was associated with a reduction in the concentration of muscle $\mathrm{K}$ and an increase in that of muscle $\mathrm{Na}$. Similar trends were evident in muscle $\mathrm{K}$ concentration in Expt 2 (although not in Expt 1) however, no significant trends in muscle $\mathrm{Na}$ with increasing dietary $\mathrm{Mg}$ were evident in either experiment. 
The shift in muscle water in $\mathbf{M g - d e f i c i e n t ~ r a t s ~ a l s o ~ e x p l a i n e d ~ t h e ~ d e c r e a s e ~ i n ~ m u s c l e ~} \mathbf{M g}$ in this animal for it was shown (Elin et al. 1971) that the concentration of $\mathrm{Mg}$ in the intracellular fluid (which is rich in $\mathbf{M g}$ ) was not significantly different in $\mathbf{M g}$-deficient and control animals. The trend seen in both the present experiments of a fall in muscle $\mathrm{Mg}$ with decreasing dietary $\mathrm{Mg}$ may be similarly due to the reduction in intracellular fluid volume. It is noteworthy that $\mathbf{M g}$ concentrations in cardiac muscle showed, in both experiments, opposite trends to that in skeletal muscle, concentrations being maintained during $\mathbf{M g}$ deficiency. Mg concentrations in cardiac muscle are lower than those in skeletal muscle and particular homoeostatic mechanisms may operate to maintain them.

Phosphorus concentrations in muscle showed opposite trends in the two experiments but there is no obvious explanation for this. While it may relate to the higher dietary $\mathbf{P}$ concentrations used in Expt 2 those used in Expt 1 are, in fact, greater than levels considered necessary for optimal growth in salmonids (Ketola, 1975; Ogino \& Takeda, 1978).

Changes in the $\mathrm{Mg}, \mathrm{Ca}, \mathrm{K}$ and $\mathrm{Na}$ concentrations in rat liver as a consequence of $\mathrm{Mg}$ deficiency were reported by Martindale \& Heaton (1964). However, MacIntyre \& Davidsson (1958) and Elin et al. (1971) failed to find any changes in the concentrations of these minerals in this tissue as a consequence of $\mathrm{Mg}$ deficiency. Our results on trout are consistent with the latter findings in that liver mineral concentrations remained constant in both experiments in response to the treatments used.

\section{REFERENCES}

Cowey, C. B., Knox, D., Adron, J. W., George, S. G. \& Pirie, B. (1977). Br. J. Nutr. 38, 127.

Elin, R. J., Armstrong, W. D. \& Singer, L. (1971). Am. J. Physiol. 220, 543.

Fisher, R. A. (1950). Statistical Methods for Research Workers. Edinburgh: Oliver \& Boyd.

George, G. A. (1976). The effect of $\mathrm{Mg}$ deficiency on the chemical composition and metabolism of soft tissues in the rat. $\mathrm{PhD}$ Thesis, University of Lancaster.

Holmes, W. N. \& Donaldson, E. M. (1969). In Fish Physiology, vol. 1, p. 14 [W. S. Hoar and D. J. Randall, editors]. New York: Academic Press.

Ketola, H. G. (1975). Trans. Am. Fish. Soc. 104, 548.

McAleese, D. M. \& Forbes, R. M. (1961). J. Nutr. 73, 94.

Maclntyre, I. \& Davidsson, D. (1958). Biochem. J. 70, 456.

Manery, J. F. (1954). Physiol. Rev. 34, 334.

Martindale, L. \& Heaton, F. W. (1964). Biochem. J. $92,119$.

Nugura, D. \& Edwards, H. M. Jr, (1963). J. Nutr. 80, 181.

O'Dell, B. L., Morris, E. R. \& Regan, W. O. (1960). J. Nutr. 70, 103.

Ogino, C. \& Chiou, J. Y. (1976). Bull. Jap. Soc. Scient. Fish. 42, 71.

Ogino, C., Takashima, F. \& Chiou, J. Y. (1978). Bull. Jap. Soc. Scient. Fish. 42, 71.

Ogino, C. \& Takeda, H. (1978). Bull. Jap. Soc. Scient. Fish. 44, 1019. 